\title{
Combining Organization Goal-Oriented Elicitation and Wireframe for Fishery Product Sales Mobile Application Design
}

\author{
Fransiskus Adikara ${ }^{1}$, Sandfreni $^{2}$ \\ \{fransiskus.adikara@esaunggul.ac.id ${ }^{1}$, sandfreni@esaunggul.ac.id $\left.{ }^{2}\right\}$ \\ Computer Science Faculty, Information System Program, Universitas Esa Unggul, Jl. Arjuna Utara No. 9, Jakarta 11510, \\ Indonesia ${ }^{1,2}$
}

\begin{abstract}
Indonesia is an island country that has a very large sea area. Indonesia supplies around $10 \%$ of world marine commodities and about $60 \%$ of Indonesia's animal protein supply comes from fish and seafood. Fishery products are one of the main traded products in Indonesia for consumption. Nowadays, using mobile applications to sale fishery product can simplify and speed up the transaction process. This research will explain and demonstrate system requirements elicitation process using Organization Goal-Oriented Requirements Engineering (OGORE) method. The result of elicitation process will be modeled in form of Initial Goal Tree Model (IGTM). Futhermore, the IGT M will be transform into Wireframe as fishery product sales mobile application design. With this research, we proposed to combine the organization goal-oriented elicitation and wireframe design process, so the result of this method can be used to develop a mobile application system for selling fishery products.
\end{abstract}

Keywords: Requirements Engineering, Mobile Application Design, Wireframe, Software Engineering.

\section{Introduction}

Using information and communication technology for sales transactions has become a common thing to do nowadays. The use of new information and communication technologies is increasing over time, especially Internet and s martphone technologies. In Indonesia, the number of Internet users in the year 2019 is about 171,2 million people or about $64.8 \%$ of the total population [1]. Web based application are being transformed into mobile applications because using mobile devices make communication and data transfer between devices easier. Business transactions using mobile devices will increase transactions speed and number.

Ministry of Maritime Affairs and Fisheries has intensely encouraged to develop and use online auction systems especially for fish and seafood market [2], because the traditional auction process is very prone to fraud [3]. Several cities in Indonesia have implemented online system usage for the fish auction [4]. However, the systemthat currently being implemented is a web based application, the system still need to be created as a native mobile based application to be use in mobile devices easily. The current government-provided system is still too difficult for fishermen to use so that the system is abandoned [5].

The systems (web-based auction system) development process in Indonesia is still experiencing difficulties. The most common problem that aris es during the systems development is the requirements en gineering process that is incomplete and can not meet the organization objectives [6]. The requirements en gineering objective is to identify the systemfunctional and non functional requirements. The requirements engineering approach provides methods, techniques, and tools to software engineers to understand the developed software goals. The requirements engineering result can also be used by stakeholders to comprehend the software usability and utilization.

In this research the Organization Goal-Oriented Requirements Engineering (OGORE) method [6] use to elicit the fishery sales system. We demonstrate how the result of requirements elicitation process in form Initial Goal Tree Model can be transform into Wireframe modeling. With this research we propose a new combination approach using OGORE and wireframing method to get systemrequirements and desain, especially for mobile application.

In this paper, we start with an explanation about our research methodology in section 2. Continue with section 3 its a literature study regarding related work in OGORE methods, its requirements elicitation process, and wireframing method. In section 4 we discuss the elicitation process and result continue with wireframe method process and result. Finally all the work we conclude it in section 5.

\section{Research Methodology}

The phase of research methodology in conducting this research is as follows: 
1. Literature study about OGORE method, fishery sales business process, and Mobile Application design method using Wireframe.

2. Using OGORE method to elicit fishery sales mobile appliaction and generate Initial Goal Tree Model (GTM) based on goals, task, and actors that elicit from Organization Goal.

3. Design fishery sales mobile application using wireframe method based on GTM.

4. Analyze the result and conclude the proposal of a new combining approach to elicit requirements with OGORE and make a mobile application design using it.

\section{Related Works}

There are several Goal-Oriented Requirements Engineering methods that are still being extended and used in the systemdevelopment process[7]. In previous research, we have developed and proposed the Organizational GoalOriented Requriements Engineering (OGORE) [6] as one type of GORE methods. OGORE method will elicit requirements based on vision, mission, and organizational goals as the main factor to get the system requirements. With OGORE method, the system requirements has priority to achieve the organization goals rather than personal interests from user requirements [8].

\subsection{OGORE}

There are three main process of OGORE [9], namely:

1. the requirements elicitation process

2. the requirements refinement process

3. the requirements analysis process.

In this research we use only the requirements elicitation process of OGORE, which consists of 3 (three) activities as follows:

1. Defining the organizational goals of the organization's vision and mission

2. Mapping the system's objectives

3. Integrating the KPI

The complete ecitation process of OGORE methods activities flow can be see in Figure 1.

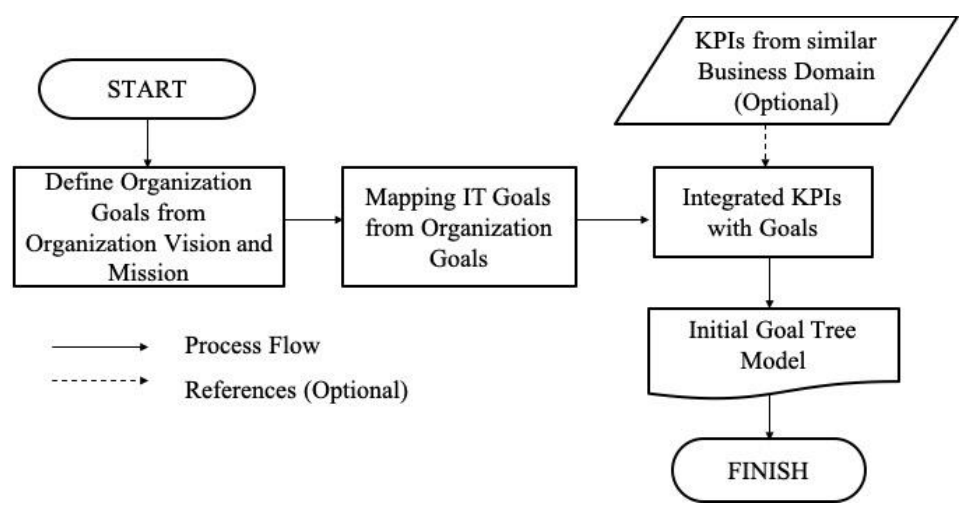

Figure 1. Organization Goal-Oriented Elicitation
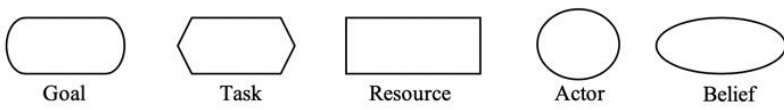

Figure 2. Goal Tree Model Elements in OGORE

The elicitation result from OGORE method will be modeled in diagram form called Initial Goal Tree Model (GTM). The Initial GTM of OGORE adapted from Goal Requirements Language (GRL)[10] modeling method. The GTM elements in OGORE are related to information systemelements. Full descriptions of these elements are in Table 1 and Figure 2. 
Tabel 1. The GTM Elements of OGORE methods

\begin{tabular}{ll}
\hline Element & Description \\
\hline Goal & Organization goal, Busines s goal, Information Technology (IT) goal, and or \\
& Information System (IS) goal to be achieved by the organization. This goal \\
& measurement is quantitativeand has a KPIfor each goal. This goal will be related to \\
& functional requirements. This element is related to the software and output elements \\
& of the information system that will be developed.
\end{tabular}

Task

A set of solutions or a series of business processes to achieve the goals that havebeen defined. This element is related to the process elements of the information system that will be developed.

Res ource

The required resources to achieve and complete goals or tasks. This element is related to the hardware and database elements in the information system that will be developed.

Actor

Business stakeholders that want goals to be achieved, taks can be done, and recource available. This element is related to human resources (brainware) element in the information system that will be developed.

Belief

The interpretation and basic principles that are trusted from an entire business process. This element is related to the process elements of the information system that will be developed.

Constraint

The interpretation of a norm and circumstance that provides limits on the achievement of the goals set. This element is related to the process elements of the information system that will be developed.

\subsection{Wireframe}

Wireframe is a rough description of each application framework[11], it is a simple black and white layouts that outline the specific size and placement of page elements, site features, conversion areas and navigation for your website (web)[12]. Wireframe is one of mobile application design method by creating a sketch of all important user internaface (UI) components, which want to be placed on the application screen. The emphasis in this wireframe method is the layout of every mobile application UI component. Using this method, the initial sketch results can be forwarded until the creation of systemprototypes, but in this paper, the discussion will be more focused on the transformation process from GTM to sketch only. The steps of the wireframe in designing mobile applications are as follows:

1. Create a sketch. Sketch is a rough representation of all the mobile application UI and function idea. The sketch can bedone on paper with the help of a pencil. Designer are free to choose some digital tools, but it is easier to sketch on paper.

2. Wireframing process. The process of developing ideas that arise when sketching. Wireframes are made with a more detailed structure and usually with the help of digital tools. There will be some improvements made to the sketch image before deciding what ideas are worth implementing and what ideas should be discarded. The result of this move is the best draft decision to be used.

3. Prototype process. Good wireframing results will be made for the prototype product. At this stage can add multiple user interfaces with thehelp of the application or can do some coding to communicate the draft in a better form.

With these two methods, the early phase of a mobile application development will produce quality products and can be developed as needed by organization.

\section{OGORE Elicitation Process to Elicit Fishery Product Sales Mobile Application Requirements}

In this research, OGORE method is usedbecause it is a requirements engineering method that can be used only based on the organization goal. The requirements elicitation process based on OGORE method purpose is to 
define the systemfunctional and non-functional requirements that supports the achievement of organization goals. This section will be discuss the detailed OGORE elicitation method stage (Figure 1).

\subsection{Define Organization Goals from Organization Vision and Mission.}

The organization goals is the general objective, purpose, and mis sion of an organization. These organization goals are defined by high-level stakeholders and socialized across org anizational elements in order to achieve them. Organization goals will be the company's philosophy in giving direction to its employees in order to fulfill the stakeholder's as pirations. The purpose of the organization within the business sphere means business goals. The purpose of the business itself is a goal or target that must be achieved by the organization [13].

The first process of OGORE method is to define the organization goal from organization vision and mis sion. In this case study, the vision of the organization used is the vision of the Directorate General of Fisheries Aquaculture Ministry of Maritime and Fisheries [14]. The Directorate General vision is accomplishing an independent, competitive and sustainable aquaculture based on national welfares. While the Directorate General missions is:

1. Accomplishing the independence of fishermen through the use of resources, based on community empowerment

2. Achieving competitive fishery products through enhancing innovative technology

3. Utilize fishery resources sustainably.

Based on this vision and mission, the most priority organization goal is to improve the welfare of the fish cultivator community and realize the sustainability of fishery resources.

\subsection{Mapping IT Goal from Organization Goal.}

Information and communication technology is an important part of the organization in order to fulfill organizational objectives. IT goal is an objective of information technology (or information system) application in a organization that aims to support the achievement of organizational objectives [15]. Alignment between organizational goal and IT goal is indispensable for organizations to accelerate the achievement of the organization goal.

In OGORE method, the results of this activity is the organization goal to be used as a primary basis for information systems development. Based on the above understanding, the activities undertaken by the stakeholders and the development team in a discussion group are as follows:

1. Define the organization vision and mission by the high-level stakeholders.

2. Define the organization goal based on organization vision and mission by the high-level stakeholders.

3. Establish priorities among the organizational goal to be mapped into IT goal.

The first two step already discuss in previous section. Bas ed on the most priority organization goal and forum discussion group between the stakeholders and the development team, the IT goal is to increase sales of fishery products. This IT goal set as foundation (root) of system requirements that we want to develop.

After clearing IT Goal, the developers team with stakeholders extracted the IT Goal. The process of IT extraction into its elements (Task, Resource, Actor, Belief, and Constraint) is done by transforming the current businessprocesses or expected business processes when having an information system. One way to get those elements by using "What" and "How" questions for each Goal you want to accomplish. For example: How do I increase fish sales? The answer to this question can be answered by decuting the new goal (sub-goal) or with a set of activity processes (tasks). After the mapping and extracting process is complete, the development team describes the Initial Goal Tree Model which links the elements above with the GRL modeling notation to be discussed with stakeholders to ensure that the Organization goal are degradable clearly on the modelled elements. The result of this process is the Initial Goal Tree Model without KPI elements (Figure 3). 


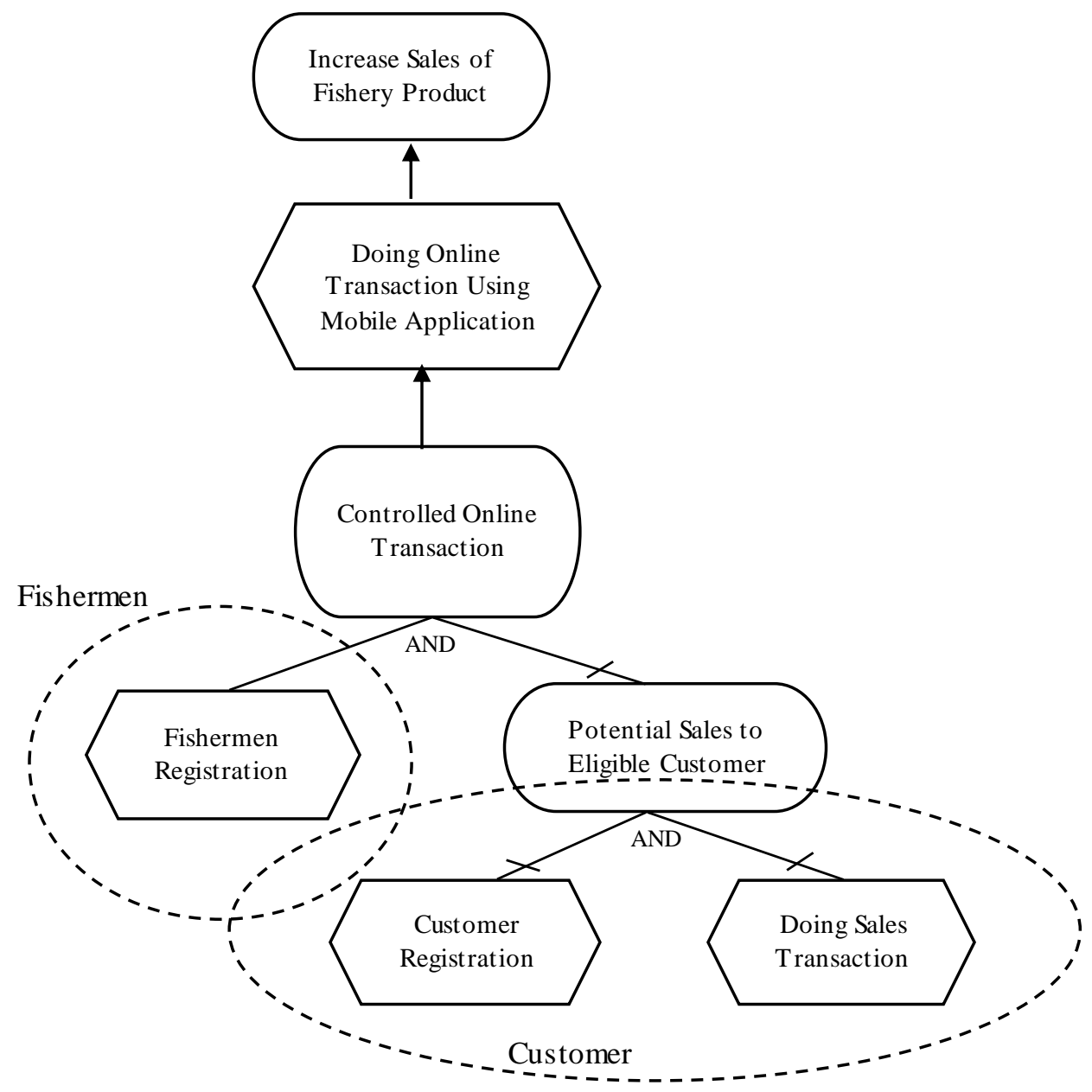

Figure 3. First version of Initial Goal Tree Model

\subsection{Integrated KPIs with Goals}

The Key Performance Indicator (KPI) is a metric of Critical Success Factor that is displayed in ratios or percentages [16]. The value of the KPI should be searchable and can present an existing performance trend. KPIS can also be defined as quantitative and qualitative measurements to show the progress of the Org anization in achieving goals.

From an existing definition, the KPI that will be set in this OGORE method is a KPI that can be a tool to demons trate the level of achievement of Goals predefined in the previous process. The types of KPIS used are direct indicators, which are indicators that provide a direct value to a condition, e.g. what percentage of the accuracy of the sales cost of the good sold (COGS), or how much accuracy of the amount of use of goods, the number of goods requested, etc.

In OGORE method, KPI is useful to controleach goal so that it can only be achieved if the element derived based on that goal (task, resource, and actor) is executed correctly as the functional needs of the system, only to To accommodate organizational objectives, not other needs. Based on the explanation, the KPI integrated with Goals in the elis itation process needs to have the ability to reduce the uncertainty that arises from the needs of the user. With KPIS, it is ensured that the main focus of achieving system functional needs is Goal based and focused on organizational objectives. 


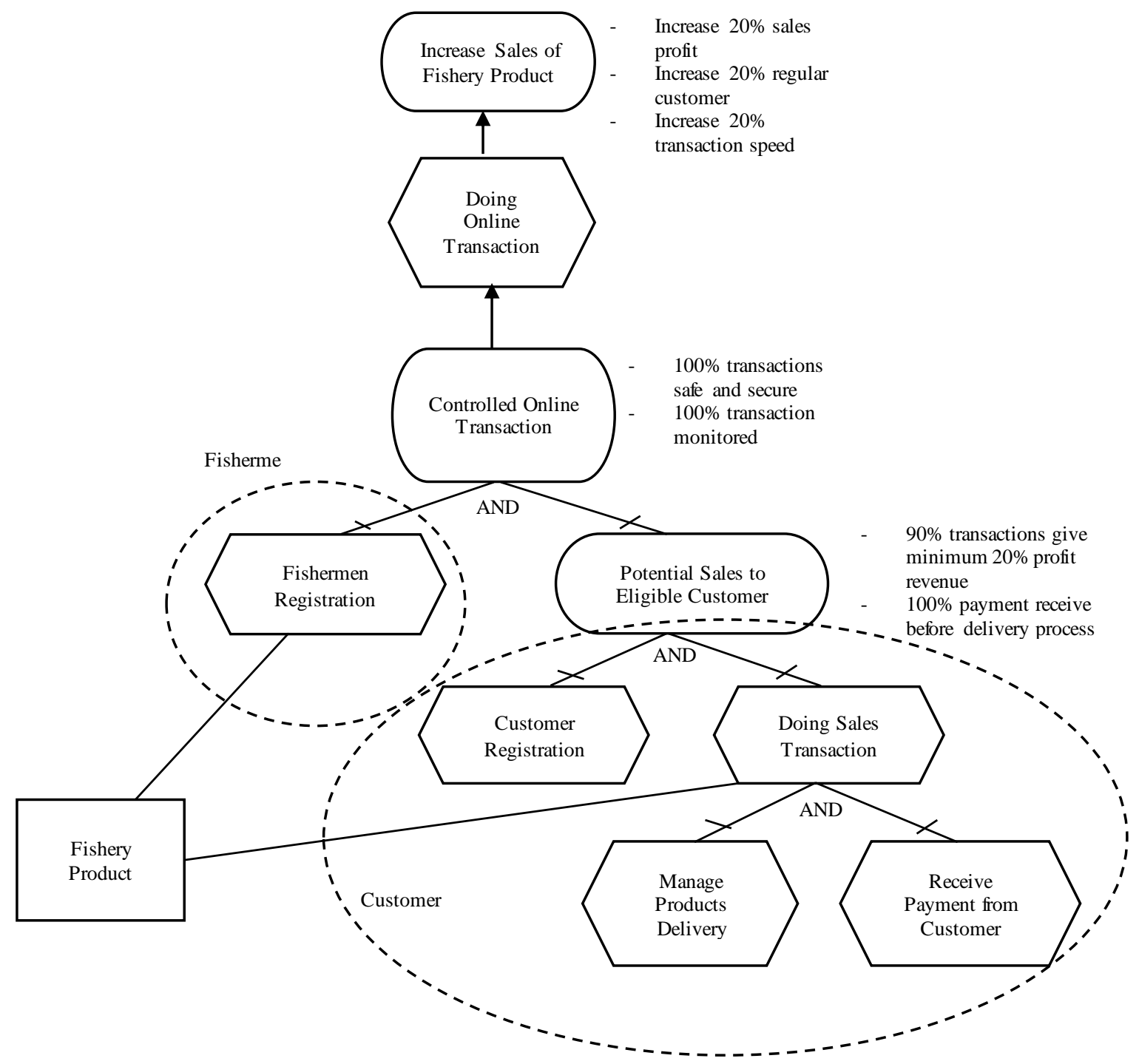

Figure 4. Initial Goal Tree Model

To identify the KPI, you do the following steps:

1. Stakeholders create a list of sizes used to evaluate the achievement of each goal.

2. From the list are indexed priorities of every size and ensure that the size can be a control. The control is that the size can only be achieved if the stakeholders and the users will use and run a well-developed information system in accordance with the provisions and objectives of the function.

3. If these conditions are met, the prioritized measures will be the KPI.

4. As a reference to assigning KPIS, the incidence can also use KPIS for goals that have been owned by organizations residing in a similar business domain[17]. It is also necessary as a benchmarking (a comparative value) of a KPI that has been assigned a stakeholder, or it is used if the business domain is already sufficiently "mature" so that the KPI that is in the business can be considered a best practice (best Practice).

5. KPI is then integrated with related goals. The KPI is described in each goal element of goal Tree Model to clarify the target achievement of the goals.

Once all is done, this elicitation process generates the Initial Goal Tree Model to illus trate the needs of the information system built and according to the expectations of the organization. 


\section{Mobile Application Design using Wire frame}

The design process using the Wireframe method was done after the Initial GTM was completed. Each element of the Initial GTM becomes the basis of the UI sketch creation of the mobile application screen. The sketch process is done together between the needs and designing team.
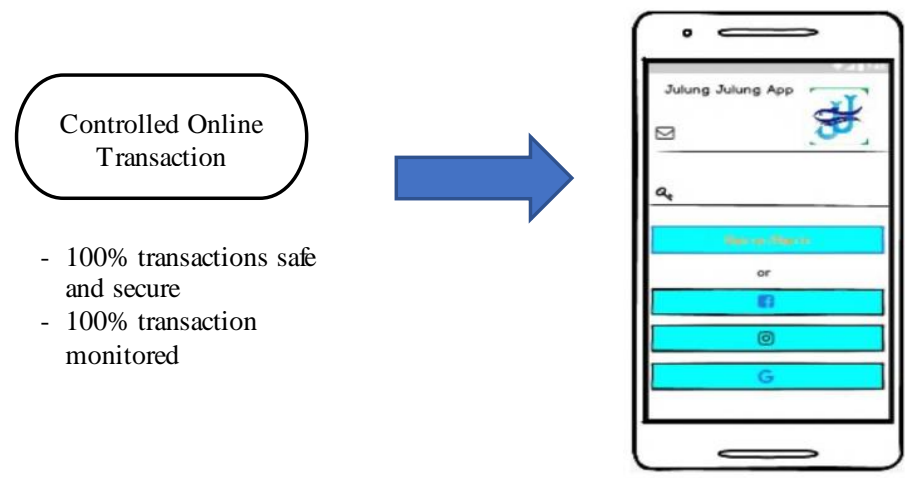

Login Page

Figure 5. Login Page
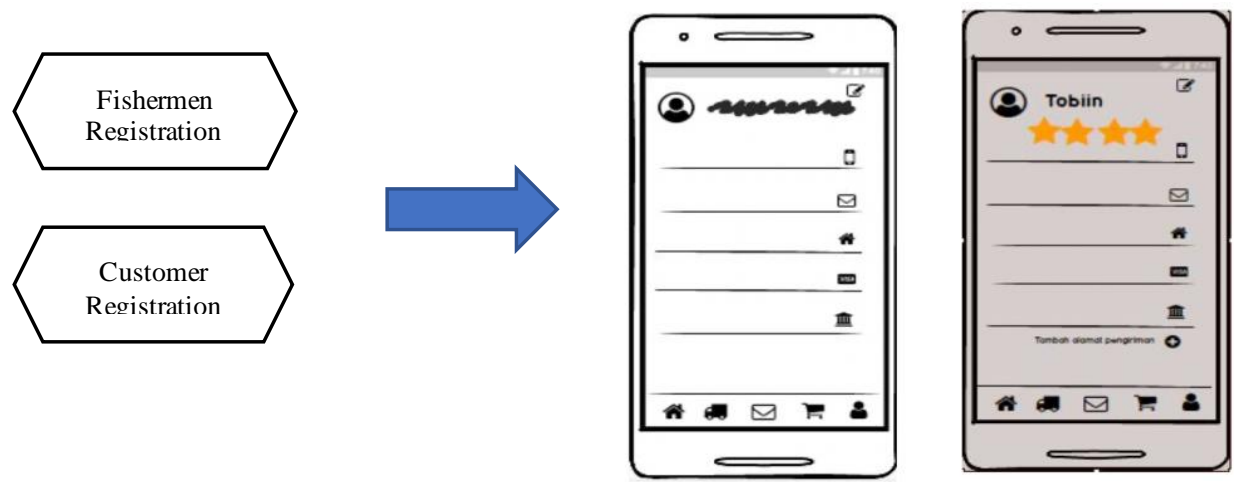

User Registration (Fishermen or Customer)

Figure 6. User Registration (Fishermen or Customer)
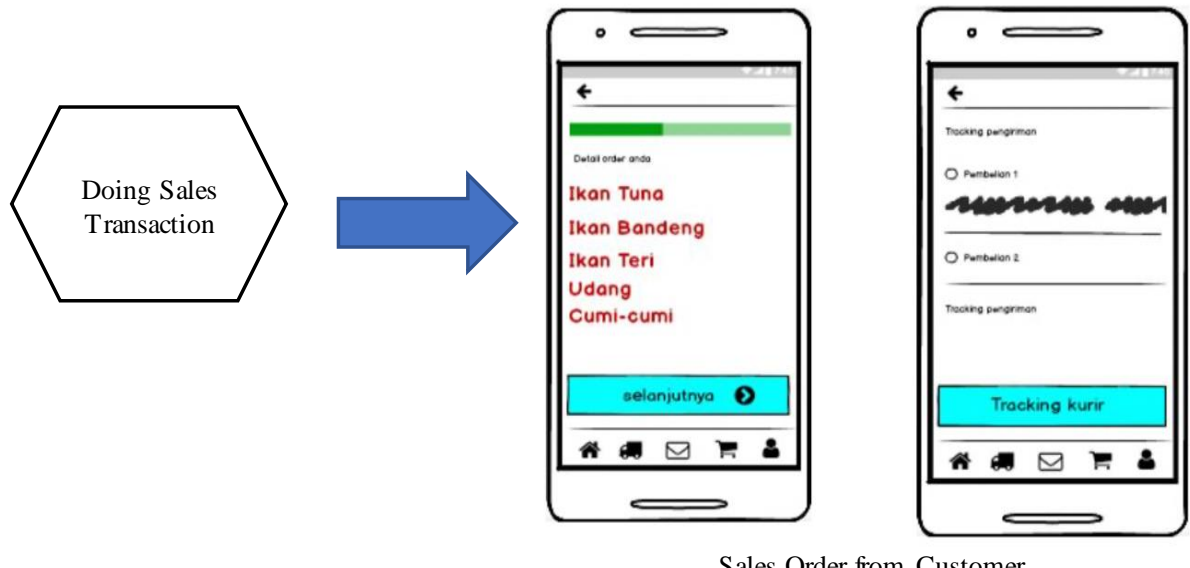

Figure 7. Sales Order from Customer 

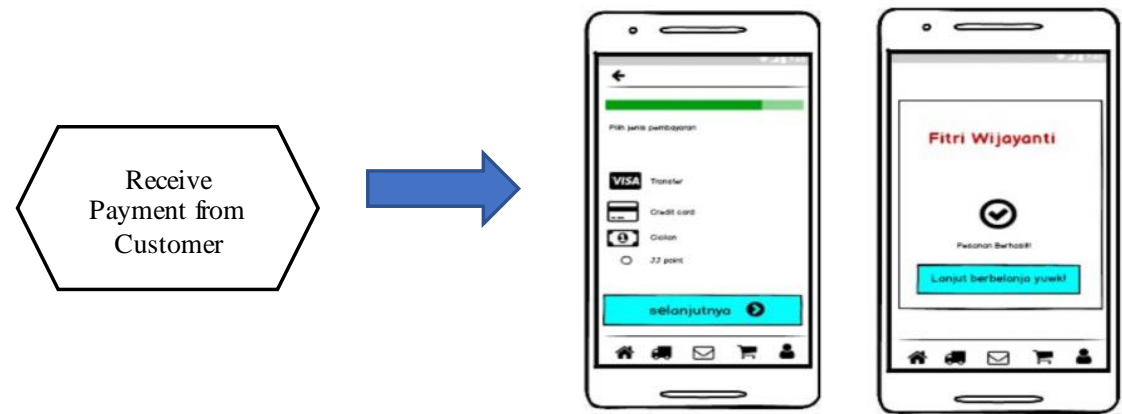

Payment Transaction

Figure 8. Payment Transaction

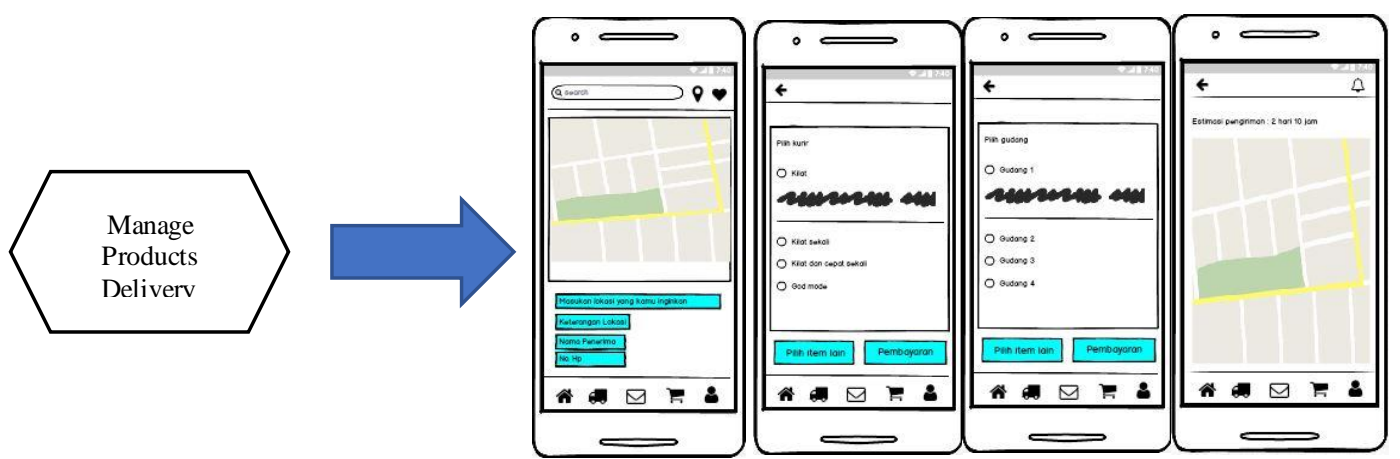

Figure 8. Delivery Management

\section{Conclusion}

The conclusion that can be obtained from this research is:

- To develop a mobile application for fishery products sales, we needs to be done requirements engineering with appropriate methods so that the entrepreneur's goal of running his online sales business in accordance with the requirements of the system developed

- Combining Organization Goal-Oriented Requirements Elicitation with Wireframe method can make sure each functional and non functional requirements of mobile application been accommodated in design phase

- This combination method can be use as one of software development early process specially for mobile application

\section{References}

[1] The Jakarta Post, “Indonesia has 171 million internet users: Study,” The Jakarta Post, 2019. [Online]. Available: https://www.thejakartapost.com/life/2019/05/18/indonesia-has-171-million-internet-users-study.html. [Accessed: 01-Sep-2019].

[2] E. Simorangkir, "Ubah Muara Baru Jadi Pasar Modern, Susi: Lelang Ikan Pakai Sistem Online,” detikFinance, 2016. [Online]. Available: https://finance.detik.com/berita-ekonomi-bisnis/d-3308271/ubah-muara-baru-jadi-pasarmodern-susi-lelang-ikan-pakai-sistem-online. [Accessed: 01-Sep-2019].

[3] I. Pratiwi, "Susi: Proses Pelelangan Ikan Saat Ini Rawan Kecurangan," Republika.co.id, 2018. [Online]. Available: https://republika.co.id/berita/pgyc6r383/susi-proses-pelelangan-ikan-saat-ini-rawan-kecurangan. [Accessed: 01-Sep2019].

[4] A. I. Juida, "Luhut resmikan tempat pelelangan ikan daring pertama di Indonesia," Antaranews, 2019. .

[5] CNN Indonesia, “Aplikasi Lelang Ikan Negara Sosialisasi ke Nelayan Sukabumi,” CNN Indonesia, 2019. [Online]. Available: https://www.cnnindonesia.com/ekonomi/20190801120637-92-417346/aplikasi-lelang-ikan-negara- 
sosialisasi-ke-nelayan-sukabumi. [Accessed: 01-Sep-2019].

[6] F. Adikara, B. Hendradjaya, and B. Sitohang, "Organization goal-oriented requirements elicitation process to enhance information system," Int. J. Electr. Comput. Eng., vol. 6, no. 6, 2016.

[7] F. Adikara, B. Sitohang, and B. Hendradjaya, "Goal-Oriented Requirements Engineering: State of the Art And Beyond," in The 2nd International Confrence on Information Technology and Business Application, 2013.

[8] F. Adikara, B. Hendradjaya, and B. Sitohang, "A new proposal for the integration of key performance indicat ors to requirements elicitation process originating from organization goals," in Proceedings of 2014 International Conference on Data and Software Engineering, ICODSE 2014, 2014.

[9] F. Adikara, B. Hendradjaya, and B. Sitohang, "Using organization goal-oriented requirements engineering result to develop sales information system," in Lecture Notes in Engineering and Computer Science, 2017, vol. 2227.

[10] D. Marosin, S. Ghanavati, and D. Van Der Linden, "A principle-based goal-oriented requirements language (GRL) for Enterprise Architecture,” CEUR Workshop Proc., vol. 1157, 2014.

[11] J. McWherter and S. Gowell, Professional Mobile Application Development. Indianapolis: John Wiley \& Sons, Inc., 2012.

[12] N. Haas, "What Is a Wireframe? 7 Reasons Why Wireframing Is Important In Web Design," Orbit Media Studio, 2011..

[13] A. Ullah and R. Lai, "MODELING BUSINESS GOAL FOR BUSINESS / IT ALIGNMENT USING REQUIREMENTS ENGINEERING," J. Comput. Inf. Syst., pp. 21-28, 2011.

[14] Dirjen Perikanan Budidaya, "Visi, Misi, dan Tujuan Dirjen Perikanan Budidaya," Dirjen Perikanan Budidaya, 2014. [Online]. Available: https://www.djpb.kkp.go.id/index.php/arsip/c/200/Visi-Misi-Tujuan/?category_id=5. [Accessed: 01-Sep-2019].

[15] IT Governace Institute, COBIT 5 Framework. 2012.

[16] FinPa New Media, Key Performance Indicators. 2009.

[17] Public Record Office Victoria, Guidelines 3: Key Performance Indicators. 2010. 